\title{
ЈАСМИНА СТОЈКОВИТ, КАТАРИНА ЗАВИШИН (2010). АМІСІ 4: италијански језик за 8. разред основне школе (Београд: Завод за уџбенике)
}

Уџбенички комплет Amici 4 састоји се од уџбеника, радне свеске, звучног материјала и приручника за наставнике. Намењен је првенствено ученицима 8. разреда основне школе, тј. четвртој години учења италијанског језика и представља наставак тријаде уџбеничких комплета Amici 1, Amici 2 u Amici 3 .

\begin{tabular}{|l|l|}
\hline Компоненте комплета & Обим \\
\hline Уџбеник & 26,5 х $20,5 \mathrm{~cm}$ \\
& 119 стр. \\
\hline Радна свеска & 26,5 x $20,5 \mathrm{~cm}$ \\
& 67 стр. \\
\hline Звучни материјал & $1 \mathrm{CD}$ \\
\hline Приручник за наставника & 23,5 х $16,5 \mathrm{~cm}$ \\
& 139 стр. \\
\hline
\end{tabular}

\section{УЏБЕНИК}

Уџбеник садржи уводни део, уводну и још шест модерно илустрованих наставних јединица и завршни део посвећен граматичким и лексичким садржајима.

\begin{tabular}{|l|l|}
\hline Уводни део & Indice \\
\hline Средишњи део & Unità introduttiva; Unità 1-6 \\
\hline \multirow{2}{*}{ Завршни део } & Appendice grammatical \\
\cline { 2 - 2 } & Vocabolario \\
\hline
\end{tabular}

У уводном делу дат је преглед садржаја, те се на основу назива наставних јединица може наслутити тематика наставних целина. Наставне целине 
носе следеће називе: Bentornati! (Добродошли); Come eravamo da bambini... (Какви смо били као деца); Facciamo il detective! (Играјмо се детектива!); Che facciamo dopo la scuola? (Шта ћемо да радимо после школе?); Quanto mi piace fare shopping!!! (Баш волим да идем у шопинг!!!); Tutti in gita! (Сви на излет!); Andiamo in Italia... per studiare! (Идемо у Италију... да би учили!).

Свака наставна јединица има јасну структуру, те се стиче утисак организованости и систематичности.

Преградне стране садрже краће информације у вези са садржајем наставне јединице, граматичким одредницама, као и културним и цивилизацијским аспектима које су увек и визуелно представљене.

Стране 1. и 2. садрже уводне текстове са илустрацијама и низ вежбања у вези са темом. Текстови су најчешће информативног и дијалошког карактера. Углавном су заступљене три врсте активности: вежба повезивања слике са текстом, опис фотографија и решавања различитих језичких задатака или вежба слушања.

Стране 3. и 4. преузимају и фиксирају лексичке и граматичке проблеме и имају функцију инпута за ученике у откривању нових граматичких облика или времена. На овим странама се налази и вежба Parliamo un po ' која се састоји од краћег језичког подстицаја у дијалошкој или текстуалној форми на основу које се развија говорна вештина. Ова вештина се увежбава и помоћу активности и пројеката за рад у пару и групи.

Стране 5. и 6. садрже нове појмове, граматичка правила и вежбања са одговарајућим инструментима за фиксирање понуђених садржаја. Смењују се следеће технике: вишеструки избор, издвајање одређених информација, повезивање слика и текста и слично. На овим странама се налазе и вежбе које подстичу ученике на усмену продукцију кроз дијалоге, рад у групама, играње улога и дискусије.

Страна 7. садржи вежбу слушања, као и разне технике за подстицање ове језичке вештине, попут вишеструког избора, заокруживање тачног одговора, издвајање тачних информација, одговарање на питања, проналажење синонима одређених израза и повезивање илустрација са одговарајућим значењима.

Страна 8. садржи активности којима се ученици подстичу на различите пројекте или дискусије у складу са темом наставне јединице.

Страна 9. садржи табелу за самосталну процену знања.

Квиз после шесте наставне јединице, осмишљен као упитник са вишеструким избором, представља проверу усвојености нових сазнања из области културе, али и језичких израза, пословица и слично. У горњем делу 
странице наводи се да квиз треба организовати по групама, а неки од садржаја приказани су и фотографијама.

Завршни део чини приказ пређених граматичких структура (Аppendice grammaticale), као и веома богат речник обрађене лексике (Vocabolario). Граматички садржај чине објашњења о употреби, грађењу граматичких облика или изузецима од правила; контекстуализовани примери са графички истакнутим елементом. Лексика је дата абецедним редом, а све речи и изрази су преведени на српски језик.

Кроз читав уџбеник заступљене су комуникативне функције прописане Програмом за основне школе. Комуникативне функције уведене у првим лекцијама понављају се и учвршћују и у наредним уз увођење нових језичких чинова. Теме у уџбенику су савремене и такође одговарају Програмом задатим темама. Језичке структуре су у оквиру задатих. Поступак организације материјала је кохерентан. Ауторке развијају сваку наставну јединицу око задате теме и путем разноврсних текстова, илустрација и прикладних вежби настоје да шире и граде материјал за нови ниво знања. Овако постављена концепција савремена је и одговара захтевима школске наставе.

\section{РАДНА СВЕСКА}

Радна свеска садржи уводну, шест наставних целина које су тематски и садржајно усклађене са уџбеником, као и укрштеницу.

\begin{tabular}{|l|l|}
\hline Уводни део & Indice \\
\hline Средишњи део & Unità $1-6$ \\
\hline Заврини део & Facciamo il cruciverba \\
\hline
\end{tabular}

Уводни део садржи линерни преглед садржаја.

Средишњи део се састоји од 6 наставних целина и сегмената намењених обнављању после парних наставних целина. То су махом веома разноврсне и тематски садржајне вежбе и активности које су у координацији са уџбеником. Полазећи од циља наставних активности, постоји правилност у наставном поступку: од развијања граматичке компетенције преко лексичке и прагматичке, па до писања састава. Око половина наставних активности јесте допуњавање текста или реченица. Остале наставне технике су: одговарање на питања, реконструисање текстова, спаривање комплементарних речи или израза, проналажење „уљеза,“ класирање речи, решавање осмосмерке, писање вођеног састава. На крају основног дела у 3. и 5. наставној иелини на- 
лазе се по две наставне активности под називом Cruciverba i Gioco dell'oca. Прва активност, конципирана у виду укрштенице, усмерена је на увежбавање лексичких елемената. У другој активности, сличној игри Не љути се човече, ученик добија задатак да се присети неколико речи, или из одређеног лексичког поља или везаних за цивилизацијски елемент.

Завршни део, такође, чини укрштеница, наставна активност усмерена на утврђивање лексичких и граматичких елемената, као и оних везаних за италијанску цивилизацију и културу.

Овако конципирана радна свеска представља додатни дидактички материјал од велике помоћи при извођењу активности и континуираног рада у оквиру једне наставне целине. Рукопис радне свеске је у складу са утврђеним стандардима квалитета уџбеника. Обухвата целокупну наставну грађу и подређен је реализацији задатака наставе. Материјал је по садржају, дужини реченице и обиму прилагођен узрасту и интересовањима ученика. Питања и задаци помажу бољем разумевању садржаја уџбеника. Презентовани садржај је у функцији процеса учења и сазнавања и доприноси развоју језичке културе. Садржи, такође, рекапитулационе и систематизујуће делове који су успешно реализовани.

\section{ЗВУЧНИ МАТЕРИЈАЛ}

Звучни материјал је приложен у облику компакт-диска (CD) који се добија уз сваки уџбеник. На компакт-диску постоје: а) снимци који се односе на садржај уџбеника (они су најбројнији), б) снимци повезани са садржајем радне свеске и в) шест песама. Снимци у вези са уџбеником су махом монолози и дијалози. Неки су одштампани у самом уџбенику, док су неки доступни само у снимљеној верзији. Снимци у вези са радном свеском нису одштампани. Текстови припадају усменој језичкој форми и у вези су са корпусом вежбања. На крају сваке наставне целине, сем оне уводне, снимљена је по једна песма чији је текст одштампан у приручнику за наставнике. Овако осмишњен звучни материјал савршено се уклапа и доприноси целини читавог уџбеничког комплета.

\section{ПРИРУЧНИК ЗА НАСТАВНИКЕ}

Приручник за наставнике садржи табеларни приказ садржаја по наставним јединицама, увод, препоруке за коришћење уџбеничког комплета Amici 4 и примену комуникативног метода, структуру наставних јединица, корисне информације везане за културу и цивилизацију, предлог тестова за 
проверу знања, лудичке активности, адресе сајтова за додатне информације и списак литературе.

\begin{tabular}{|c|c|}
\hline \multirow[t]{4}{*}{ Уводни део } & Садржај \\
\hline & Табеларни приказ садржаја по наставним јединицама \\
\hline & $У_{в о д}$ \\
\hline & Уибенички комплет Amici 4 \\
\hline Средишњи део & Уводна наставна јединица и наставне јединице 1 - 6 \\
\hline \multirow[t]{5}{*}{ Заврини део } & Култура и циивилизачија \\
\hline & Тестови \\
\hline & Лудичке активности \\
\hline & Корисни сајтови \\
\hline & Литература \\
\hline
\end{tabular}

Приручник садржи и решења свих вежби из Уџбеника и Радне свеске, транскрипт целокупног снимљеног материјала, препоруке за рад, али и друге корисне информације и документе. Наставне јединице су описане кроз детаљан приказ. Дат је и предлог за увод у сваку нову наставну јединицу. Комуникативне функције дате су са примерима. Технике и активности као избор у наставном процесу у великој мери олакшавају остваривање програма. Упутство за коришћење радне свеске доприноси и континуираном раду у оквиру једне наставне целине. Улога наставника и ученика јасно је истакнута. Приручник даје и методско упутство о примени граматике. Нуди елементе за проверу и оцењивање што додатно омогућава наставнику да на адекватан начин провери количину усвојеног знања. Додатне активности дате након тестова додатно обогаћују и од велике су помоћи при извођењу активности.

Креативност у извођењу садржаја, лудичке активности, као и сами цивилизацијско-културолошки аспекти који додатно приближавају ученицима елементе италијанске цивилизације омогућавају стварање позитивне климе у учионици, као и одржавање саме мотивације. Адресе сајтова и наведене библиографске јединице су од велике помоћи наставницима како у учионици тако и у личном формирању и усавршавању.

У питању је веома детаљан и исцрпан приручник. Он помаже у примени наставног програма, али и даје предлоге за спровођење наставе италијанског језика четврте године учења. Инспирише наставнике за нешто другачију, али адекватну примену програма у постојећим условима. 


\title{
ЗАКљУЧАК
}

Уџбенички комплет Amici 4 Јасмине Стојковић и Катарине Завишин урађен је у складу са савременим тенденцијама у изучавању страних језика и, осим што садржи Програмом предвиђене комуникативне функције, структуре и речник, упознаје ученике и са елементима културе и цивилизације земље чији се језик изучава. Композиција рукописа подређена је реализацији задатака наставе и усклађена је са предвиђеним бројем часова (68 школских часова). Рукопис стимулише креативност и радозналост и заступа комуникативни и интерактивни приступ у настави италијанског језика. Избор и распоред градива одговарају дидактичко-методичким принципима и подстичу активан однос према наставној грађи. Уџбеник, такође, подстиче ученике да самостално користе литературу. Графички део рукописа и илустровани делови су повезани са текстовима у смисаоне целине.

Уџбенички комплет Amici 4 Јасмине Стојковић и Катарине Завишин се у потпуности уклапа у циљеве и исходе наставе страних језика и као комплет одговара потребама деце и наставника при извођењу наставе како у школском тако и ваншколском амбијенту.

\author{
Снежана 3. Детар Јевђовић \\ ОШ „Петар Петровић Његош“ \\ Београд \\ biancaneve301@hotmail.com
}

